\title{
Overcoming crisis strategies in the face of the growth of market competitiveness
}

\begin{abstract}
Recent business conditions are dominated by the awareness that productivity and the effectiveness of both the economy and society in general are likely to be increased by the purposeful strengthening of competitiveness. To that effect, the results of the application of strategies aimed at overcoming the crisis and raising competitiveness are evident from the perspective of the contribution they make to economic development. This brief article explores some aspects of these issues from the perspective of the strategic options facing organisations in the Serbian economy, including state support for struggling companies, the need for a new market orientation for economic organisations and the development of an efficient market economy in line with global standards and of a regulatory approach which is based on the actual situations facing companies in both the economic and the public sectors. The authors call for a fundamental strategic approach as a means of advancing both organisational and economic competitiveness. ${ }^{1}$
\end{abstract}

Keywords: economic development, new business models, competition, efficient resource allocation, financial and economic crisis, state support, policy levers, transition

\section{Introduction}

In terms of market operations, economic development implies not only a new concept but modern models of managing the development and functioning of the economy. The economic environment promotes numerous particularly intangible parameters which are of growing importance to the market of business operations, such as: customer satisfaction; business image; emotional intelligence; business innovation; competitive intelligence; and, finally, the satisfaction of employees themselves.

In these circumstances, it is simply impossible to talk about economic development without focusing on one of the key problems of the economy in Serbia, i.e. its low competitiveness. This points to the essential part of overall economic change being the creation of a competitive economy based on the development of competitive products and services made (or realised) by economic enterprises.

1 This paper is a part of a series of research activities within the framework of a project funded by the Ministry of Science and Environmental Protection entitled 'Strategic Options of the Serbian Economy: Networking into Global Economic Trends' (Rec. No. 149060). 


\section{Implications of business strategies for the competitiveness of national economies}

The global competitiveness index best shows the level of competitiveness within an economy. The reasons why an economy demonstrates a low level of competitiveness could be numerous, but are frequently found in a disadvantageous structure of exports: namely, in the quality of the products that companies place on foreign markets. Where an economy's exports are based on labour intensive production, the products themselves are characterised by a low rate of finalisation and they have negative implications for macro-economic development. Products with such low levels of final processing are cheap and so their level of competitiveness is based on pricing parameters. Higher competitiveness may be realised by non-pricing factors on the global market such as: the quality, design and functionality of products; reliability; fast delivery; a guarantee system; maintenance; competitive intelligence; organisation; and market-entry marketing pitches.

Low levels of competitiveness can be influenced by the presence of monopolies. A state is duty bound to discourage, via specific macro-economic policy instruments, any monopolistic tendencies and to try to realise the perfect competitiveness of its market. These actions lead to higher levels of competition on the national market and, indirectly, on the international market as well.

There is neither an easy nor a fast way for an economy to remove the numerous and massive determinants of any non-competitiveness. When it comes to a national economy, appropriate solutions may be found both in its liberalisation and in its wide opening up to the world, together with the fundamental abolition of tariff barriers. The dynamics of the transformation of a non-competitive national economy into a competitive one must be synchronised with a restrained speed of the installation of new institutional mechanisms, which should facilitate the far-reaching re-allocation of resources. On the contrary, a market economy which is not institutionally equipped will not be able to engage and efficiently and effectively use these resources.

Of key importance for a national economy is that the state builds an adequate institutional infrastructure and creates optimal conditions for competition. The radical liberalisation which has been carried out in countries in transition has contributed to the additional reduction of national production, stemming from a reduction in the average import tariff rate and in the partial abolition of non-customs restrictions. This situation has led to a decrease in the value of companies that were moved, in the circumstances of mass privatisation, into the hands of new owners at extremely low prices.

Bearing in mind that the privatisation process in countries in transition has been mostly completed, it is useful to compare these results to those of other national economies. Countries in transition have been often faced with the problem of the absence of a general consensus on privatisation. The main goal in some countries has been the realisation of budget revenues rather than the re-investment of privatisation revenues in the development of the national economy. Such a situation has been quite convenient for international capital since it has enabled global creditors to gain favourable profits through the permanent borrowings made by national economies in transition. 
In order to achieve competitiveness at the national level, countries must take constructive actions as regards their budget expenditures and tax policies. In some countries in transition, the reduction of budgetary expenditure has caused the additional reduction in the purchasing power of public service employees and, therefore, a partial decrease in demand. In addition to that, high taxes have had a negative impact on prices and have led to high rates of inflation - a cause of the restrictive monetary policies implemented by the central banks of national economies. Such tax and monetary policies have resulted in a reduction in GDP growth, a decrease in the rate of employment and an additional fall in the standard of living. These situations have reduced the possibilities of earning money, causing an outflow of speculative capital from national economies and leading also to the depreciation of national currencies.

The stability of an economic environment can not be achieved without a stable currency. This leads to the ability to control inflation and attracts financial investors who can make money through high interest rates and who withdraw in circumstances of financial crisis.

In countries in transition, the effects of this are reflected in low economic activity, high levels of external indebtedness and rates of unemployment and in a reduced social security system. However, it is not only the oligarchy of the major representatives of capitalism, that are all too ready to suggest their own ready-made reform programmes, who may be blamed for the situation in which some under-developed countries find themselves, but also the national political and economic elites for accepting and implementing such programmes.

It is therefore necessary, from the aspect of the increase of competitiveness, to ensure the opening up of national markets and the establishment of economic growth and development based on the expansion of the financial services sector and on the increase of trade and dependent economic activities, even though these are factors which are not present in conditions of global financial crisis.

The crisis can often be identified in the following areas: ownership relations; managerial functions; development; markets; manufacturing; finance; personnel; and others. Overcoming the crisis requires a planned and co-ordinated influential approach to certain segments of both the business system and the economic-financial flows. The state of crisis is associated with the failure to manage both the operations of business entities and national economies.

Practical knowledge and experience in the area of overcoming crisis and in the revitalisation of companies are of the greatest importance in defining the directions that should be followed for the purpose of reducing the gap between global and national economies. Research into problems in terms of achieving competitiveness in developed market economies is somewhat different from the situation in countries in transition. Common, however, is that failure, problems in business operation and crisis itself are integral parts of corporate life cycles in all parts of the world. There are more companies that are not successful and that collapse than there are successful ones. The strategic options applied for the purpose of overcoming crisis and achieving competitive market positions are probably the only differences between them.

Problems of competitiveness and in overcoming crisis are subjects of numerous theoretical and empirical research projects, indicating that most companies have tried 
to overcome their problems by organisational restructuring and by implementing appropriate business strategies. Indeed, the analysis of approaches to overcoming the problems of competitiveness and crisis in countries in transition may be focused on the corporate world as a whole, given the intention to realise structural changes both in the model of business operation and in the business stability of a company.

In order to overcome economic crisis, it is necessary to implement many changes at the global level, as well as within companies themselves, and to build relevant strategies towards achieving competitiveness from the perspective of economic growth and development.

A successful strategy for achieving competitiveness has to comprise many elements and measures influencing the removal of the causes of a crisis. It is necessary to establish, on the basis of research, appropriate measures for specific groups of unsuccessful companies, such as: change in management procedures; organisational change; reduction of operating costs; changes in financial operation; marketing improvements, a focus on new products and services; investment; and others.

In formulating a successful competitive strategy, it is necessary, in addition to these factors, to have regard to the ongoing strategic and operational state of a company, taking into consideration a combination of numerous continuing operational measures. Preparation of strategic and operational plans aimed at a growth in market competitiveness is an integral part of that phase.

It is also of essential importance that all registered small, medium and large companies within national economies are solvent, i.e. are capable of regularly clearing their obligations to suppliers and being able to pay wages and taxes on a timely basis.

If the opposite is the case, it is possible to find solutions through state aid, in the form of funds allocated to insolvent companies on the condition that these debts are provisionally converted into proportionate shares in the company's capital. This could be a way to initiate the starting-up of the production process in a company that has been allocated financial resources of this kind. Income tax and all accounting contributions are paid into a separate state account, meaning that all tax and contribution revenues are not directed into general treasury revenues but into a specific state account. This is a means of preventing the breaking of ownership relations within a company, because the state share in a company would be provisional, established as security for the state in respect only of its allocated funds. After a specific period, a company returns the borrowed funds, resulting in the cessation of any state-owned capital share in the company. The taxes and contributions paid to the specific state account essentially represent a tax loan to an insolvent company which must repay it as soon as the appropriate economic and financial conditions are fulfilled.

\section{Conclusion}

The national economies of some transition countries have experienced a high cost for their acceptance of universal reform programmes, resulting in a reduction in national wealth, in faulty management of their economies and in the dissipation of resources as well as impoverishment of the social domain. It is recently obvious that liberalisation 
and privatisation processes which are applied without any institutional arrangements result in problems such as those experienced by certain national economies.

The global economic crisis has caused instability, a loss of markets and isolation from technological advancement. It has delayed national economic development processes to a considerable extent, implying a necessity for three key policy levers to be considered: interest rate; currency exchange rates; and the rate of taxation. The aim of economic policy is neither a reasonable fiscal policy nor a stable currency rate, low taxes and deregulation: these are nothing but instruments that should provide for the realisation of the ultimate goal - sustainable growth and the well-being of residents at the level of the national economy.

The strengthening of the market orientation of national enterprises will, in the period to come, promote the development of their competitiveness. By the application of adequate business strategies, a recovery of national enterprises could be expected in all branches of the economy, through the establishment of a favourable business climate and the development and implementation of consistent business programmes, as well as through a successful overcoming of the crisis.

The key strategy for the achievement of competitiveness comprises the creation of an efficient market economy which is in compliance with global standards and with a definition of regulation which establishes proper communication on the basis of the actual condition of both public and economy-financial sectors.

\section{References}

Berman, K. Dz (2006) Finansijska inteligencija Asee: Novi Sad.

Cvetković, N and S. Grgurević (2007) Stvarno i Moguće - Poslovni ambijent i reforme u Srbiji 2000-2007 DEB, Tematski zbornik radova: Poslovni ambijent: efekti na razvoj realnog i finansijskog sektora prvrede Srbije: Banja Koviljača.

Cvetković, N, S. Grgurević and B. Ilić (2005) Restrukturiranje preduzeća kao faktor prevazilaženja krize Ekonomski vidici, DEB, godina X, br. 2, april, Beograd: 213-219.

Cvetković, N and S. Kotlica (2007) Nova ekonomija u svetu koji se menja Megatrend University, Beograd.

Draker, P (2005) Management in New Society ASEE Books.

Grk, S, N. Cvetković and M. Vidas-Bubanja (2008) 'Promena kamatne stope - potencijalni rizik za investitore i banke u ambijentu finansijske krize’ Megatrend Revija Megatrend University.

Helfet, E. A (2001) Financial Analysis Tools and Techniques McGraw-Hill.

Ilić, B and V. Milićević (2009) Menadžment troškova - Strategijski okvir Fakultet organizacionih nauka Univerziteta u Beogradu.

Jefferson Institute (2003) Konkurentnost privrede Srbije Beograd: Jefferson Institute uz podršku Narodne banke Srbije.

Kolodko, G (1998) 'Economic neoliberalism is irrelevant' Transition 9(3). 
Kovačević, M (2009) Uzroci i posledice svetske ekonomske krize i efekti Nova srpska politička misao: Beograd.

Langović, M. A, T. Cvetkovski and V. Cvetkovska Ocokoljić (2009) 'Strane direktne investicije i mogućnost za planiranje ljudskih resursa’ (stanje u Srbiji), časpois Megatrend Revija Megatrend University.

Milićević, V and B. Ilić (2009) Efektivni menadžment troškova i merenje profitabilnosti po kupcima časopis Management broj 53, Fakultet organizacionih nauka: Beograd.

Porter, M. E (1985) Competitive Advantage New York: The Free Press.

http://www.shts.org.yu/srpska/p_stats.html. 